Sitasi artikel ini (APA $6^{\text {th }}$ Edition style):

Sianturi, R. (2019). Meningkatkan Minat Belajar Siswa pada Kompetensi Dasar Politik Luar Negeri Melalui Penggunaan Model Pembelajaran Kooperatif Tipe Tari Bambu Kelas IVB SD Negeri 067690 Medan Johor. MUKADIMAH, 2(2), 11-22.

\title{
MENINGKATKAN MINAT BELAJAR SISWA PADA KOMPETENSI DASAR POLITIK LUAR NEGERI MELALUI PENGGUNAAN MODEL PEMBELAJARAN KOOPERATIF TIPE TARI BAMBU KELAS IVB SD NEGERI 067690 MEDAN JOHOR
}

\author{
Ruster Sianturi \\ Guru SD Negeri 067690 Medan Johor
}

\begin{abstract}
ABSTRAK
Penelitian ini bertujuan untuk meningkatkan hasil belajar siswa pada kompetensi dasar politik luar negeri melalui penggunaan model pembelajaran kooperatif tipe tari bambu. Dalam penelitian ini penulis menggunakan jenis penelitian tindakan kelas (PTK) yang bertujuan untuk memperbaiki proses pembelajaran dalam meningkatkan minat belajar PKn siswa dengan menggunakan model pembelajaran kooperatif tipe tari bambu. Subjek dalam penelitian ini adalah seluruh siswa Kelas IVB SD Negeri 067690 Medan Johor. Objek penelitian ini adalah peningkatan minat belajar melalui penggunaan model pembelajaran kooperatif tipe tari bambu pada mata pelajaran PKn siswa Kelas VB SD Negeri 067690 Medan Johor.yang berjumlah 30 orang. Berdasarkan hasil analisis data diperoleh kesimpulan bahwa minat belajar siswa siklus I rata-rata nilai keseluruhan yang diperoleh hanya mencapai 44\% yang diperoleh sebesar 55\%. Pada siklus II rata-rata nilai keseluruhan yang diperoleh yaitu sebesar $69 \%$ yang diperoleh adalah sebesar $87 \%$. Pada siklus II dapat dilihat bahwa guru sudah meningkatkan penggunaan model pembelajaran kooperatif tipe tari bambu dengan baik dan perilaku belajar siswa sudah meningkat.
\end{abstract}

Kata Kunci: Politik Luar Negeri, Model Pembelajaran Kooperatif Tipe Tari Bambu.

\section{PENDAHULUAN}

Masalah pendidikan merupakan masalah yang sangat penting, karena pendidikan itu akan sangat berpengaruh terhadap perkembangan hidup manusia. Dengan semakin tingginya jenjang pendidikan yang ditempuh seseorang maka semakin besar pula kesempatan untuk meraih sukses hidup di masa mendatang. Secara garis besarnya, pendidikan sangat berkompeten dalam kehidupan, baik kehidupan diri sendiri, keluarga, masyarakat, maupun kehidupan bangsa dan negara. 
Untuk mencapai tujuan tersebut, pemerintah mendirikan lembaga pendidikan salah satunya adalah Sekolah. Sekolah sebagai tempat proses belajar mengajar mempunyai kedudukan yang sangat penting dalam dunia pendidikan. Oleh karena itu pendidikan di sekolah memegang peranan penting dalam rangka mewujudkan tercapainya pendidikan nasional secara optimal seperti yang diharapkan untuk mencerdaskan anak bangsa. Belajar adalah key term (istilah kunci) yang paling vital dalam setiap usaha pendidikan, sehingga tanpa belajar sesungguhnya tidak pernah ada pendidikan. Sebagai suatu proses, belajar hampir selalu mendapat tempat yang luas dalam berbagai disiplin ilmu yang berkaitan dengan upaya kependidikan.

Minat adalah suatu rasa lebih suka dan rasa keterikatan pada suatu hal atau aktivitas, tanpa ada yang menyuruh. Minat pada dasarnya adalah penerimaan akan suatu hubungan antara diri sendiri dengan sesuatu di luar diri. Semakin kuat atau dekat hubungan tersebut, semakin besar minat. Suatu minat dapat diekspresikan melalui suatu pernyataan yang menunjukkan bahwa siswa lebih menyukai suatu hal daripada hal lainnya, dapat pula dimanifestasikan melalui partisipasi dalam suatu aktivitas. Minat tidak dibawa sejak lahir, melainkan diperoleh kemudian. Siswa yang memiliki minat terhadap subyek tertentu cenderung untuk memberikan perhatian yang lebih besar terhadap subyek tersebut.

Menurut Slameto (2010:180), "Minat adalah suatu rasa lebih suka dan rasa keterikatan pada suatu hal atau aktivitas, tanpa ada yang menyuruh". Minat pada dasarnya adalah penerimaan akan suatu hubungan antara diri sendiri dengan sesuatu di luar diri. Semakin kuat atau dekat dengan hubungan tersebut, semakin besar minat. Suatu minat dapat diekspresikan melalui suatu pernyataan yang menunjukkan bahwa siswa lebih menyukai sesuatu hal daripada hal lainnya, dapat pula dimanifestasikan melalui partisipasi dalam suatu aktivitas. Siswa yang memiliki minat terhadap subyek tertentu cenderung untuk memberikan perhatian yang lebih besar terhadap subyek tersebut. Minat tidak dibawa sejak lahir, melainkan diperoleh kemudian. Minat terhadap sesuatu dipelajari dan mempengaruhi belajar selanjutnya serta mempengaruhi penerimaan minat-minat baru. Jadi, minat terhadap sesuatu merupakan hasil belajar dan menyokong belajar selanjutnya. Mengembangkan minat terhadap sesuatu pada dasarnya adalah membantu siswa melihat bagaimana hubungan antara materi yang diharapkan untuk dipelajarinya dengan dirinya sendiri sebagai individu.

Lebih lanjut Djaali (2008:121) menjelaskan bahwa minat adalah penerimaan akan suatu hubungan antara diri sendiri dengan sesuatu di luar diri. Semakin kuat atau dekat hubungan tersebut, maka akan semakin besar minatnya. Kegiatan yang diminati seseorang akan diperhatikan secara terusmenerus yang disertai dengan rasa senang. Jadi berbeda dengan perhatian, karena perhatian sifatnya sementara (tidak dalam waktu yang lama) dan belum tentu diikuti dengan perasaan senang, sedangkan minat selalu diikuti dengan perasaan senang dan dari situ diperoleh kepuasan. 
Menurut Slameto (2003:58) siswa yang berminat dalam belajar mempunyai ciri-ciri sebagai berikut: (1) Mempunyai kecenderungan yang tetap untuk untuk memperhatikan dan mengenang sesuatu yang dipelajari secara terus menerus, (2) Ada rasa suka dan senang pada sesuatu yang diminati, (3) Memperoleh suatu kebanggaan dan kepuasan pada sesuatu yang diminati, ada rasa keterikatan pada sesuatu aktivitas-aktivitas yang diminati, (4) Lebih menyukai suatu hal yang menjadi minatnya daripada yang lainnya, (5) Dimanifestasikan melalui partisipasi pada aktivitas dan kegiatan.

Salah satu upaya yang dapat dilakukan untuk meningkatkan minat belajar siswa adalah dengan menggunakan model pembelajaran yang menarik bagi siswa. Selain itu model pembelajaran yang menunjang aktifitas siswa belajar dengan model pembelajaran yang aktif dan tidak monoton akan membantu meningkatkan minat belajar siswa. Salah satunya adalah dengan menggunakan model pembelajaran kooperatif tipe tari bambu. Menurut Lie (2010:67) tari bambu adalah suatu pendekatan untuk melibatkan siswa dalam kelompok-kelompok kecil untuk berdiskusi, menelaah materi yang tercakup dalam suatu pelajaran dan mengecek pemahaman mereka terhadap isi pelajaran tersebut.

Teknik ini diberi nama Tari Bambu, karena siswa berjajar dan saling berhadapan dengan model yang mirip seperti dua potong bambu yang digunakan dalam Tari Bambu Filipina yang juga popular di beberapa daerah di Indonesia. Dalam kegiatan belajar mengajar dengan teknik ini, siswa saling berbagi informasi pada saat yang bersamaan. Pendekatan ini bisa digunakan dalam beberapa mata pelajaran, seperti ilmu pengetahuan sosial, agama, matematika, dan bahasa. Bahan pelajaran yang paling cocok digunakan dengan teknik ini adalah bahan yang membutuhkan pertukaran pengalaman, pikiran, dan informasi antarsiswa. Salah satu keunggulan teknik ini adalah adanya struktur yang jelas dan memungkinkan siswa untuk berbagi dengan pasangan yang berbeda dengan singkat dan teratur. Selain itu, siswa bekerja dengan sesama siswa dalam suasana gotong royong dan mempunyai banyak kesempatan untuk mengolah informasi dan meningkatkan keterampilan berkomunikasi. Tari bambu bisa digunakan untuk semua tingkatan usia anak didik.

Menurut Anita Lie (2010:67), “Adapun langkah-langkah kegiatan Tipe Tari Bambu adalah: (1) Separuh kelas (atau seperempat jika jumlah siswa terlalu banyak) berdiri/duduk berjajar. Jika ada cukup ruang, mereka bisa berjajar di depan kelas. Kemungkinan lain adalah siswa berjajar di sela-sela deretan bangku. Cara kedua ini akan memudahkan pembentukan kelompok karena diperlukan waktu yang relative singkat, (2) Separuh kelas lainnya berjajar dan menghadap jajaran yang pertama, (3) Dua siswa yang berpasangan dari kedua jajaran berbagi informasi, (4) Kemudian, satu atau dua siswa yang berdiri di ujung salah satu jajaran pindah ke ujung lainnya di jajarannya. 
Mengembangkan minat terhadap sesuatu pada dasarnya adalah membantu siswa melihat bagaimana hubungan antara materi yang diharapkan untuk dipelajarinya dengan dirinya sendiri sebagai individu. Proses ini berarti menunjukkan pada siswa bagaimana pegetahuan atau kecakapan tertentu mempengaruhi dirinya, melayani tujuan-tujuannya, memuaskan kebutuhankebutuhannya. Bila siswa menyadari bahwa belajar merupakan suatu alat untuk mencapai beberapa tujuan yang dianggapnya penting dan bila siswa melihat bahwa hasil dari pengalaman belajarnya akan membawa kemajuan pada dirinya, kemungkinan besar ia akan berminat (dan bermotivasi) untuk mempelajarinya. Model pembelajaran kooperatif tipe tari bambu merupakan model pembelajaran yang tepat dipilih dan dipergunakan untuk meningkatkan minat belajar siswa. Dalam metode ini siswa bermain seperti yang dialami dalam kehidupan mereka sehari-hari sehingga penerapan metode ini siswa lebih aktif dalam mengikuti pelajaran.

\section{METODE}

Dalam penelitian ini penulis menggunakan jenis penelitian tindakan kelas (PTK) yang bertujuan untuk memperbaiki proses pembelajaran dalam meningkatkan minat belajar PKn siswa dengan menggunakan model pembelajaran kooperatif tipe tari bambu. Subjek dalam penelitian ini adalah seluruh siswa Kelas IVB SD Negeri 067690 Medan Johor. Objek penelitian ini adalah peningkatan minat belajar melalui penggunaan model pembelajaran kooperatif tipe tari bambu pada mata pelajaran PKn siswa Kelas VB SD Negeri 067690 Medan Johor.yang berjumlah 30 orang. Pengumpulan data sesuai dengan tujuan penelitian ini, maka pengumpulan data diperoleh melalui observasi yang dilakukan oleh guru bersama guru lain (kolaborasi) SD Negeri 067690 Medan Johor.dokumentasi meningkatkan minat belajar siswa dalam pokok bahasan politik luar negeri. Pengelolaan data yang dilakukan, mempergunakan model pembelajaran tipe tari bambu. Pengumpulan data dalam penelitian ini dilakukan melalui observasi dan tes.

Analisis ini digunakan untuk mengetahui berhasil atau tidaknya tindakan yang dilakukan dengan menggunakan rumus untuk variabel minat, menurut Dewi (2009:114) adalah sebagai berikut:

Keterangan:

P: Angka minat

F: Jumlah siswa yang mengalami perubahan

$\mathrm{N}$ : Jumlah seluruh siswa

Untuk menghitung data individu, menurut Muslich (2011:161), maka digunakan rumus:

Kriteria untuk menentukan keberhasilan tindakan dalam minat belajar siswa sebagai berikut: 
Sangat berminat $\quad: 86 \%-100 \%$, dari jumlah siswa tiap indikator

Berminat $\quad: 71 \%-85 \%$, dari jumlah siswa tiap indikator

Cukup berminat $: 60 \%-70 \%$, dari jumlah siswa tiap indikator

Kurang berminat $\quad:<60 \%$, dari jumlah siswa tiap indikator

\section{HASIL DAN KESIMPULAN}

\section{Siklus I}

\section{Perencanaan}

Guru mempersiapkan siklus I dengan beberapa kegiatan dalam pembelajaran dan instrumen penelitian siswa dengan menerapkan pembelajaran yang menggunakan model pembelajaran kooperatif tipe tari bambu dengan membagi siswa dalam kelompok belajar. Adapun Standar Kompetensi (SK) yang dibahas dalam kegiatan pembelajaran tersebut adalah memahami politik luar negeri . Dengan kompetensi Dasar (KD) menanggapi politik luar negeri disampaikan secara lisan serta menyusun kelompok belajar siswa.

Langkah-langkah yang disusun dalam RPP dengan menggunakan model pembelajaran kooperatif tipe tari bambu, dimana model pembelajaran ini akan mengaktifkan siswa untuk mempelajari dan mengerjakan latihan baik secara individu maupun berkelompok. Sedangkan instrumen penelitian adalah lembar observasi. Pada siklus ini dilakukan 2 kali pertemuan, pertemuan berlangsung selama 4 jam pelajaran (4 x 35 menit).

\section{Pelaksanaan}

Pada kegiatan ini guru menerapkan penggunaan model pembelajaran kooperatif tipe tari bambu yang bertujuan untuk meningkatkan minat belajar siswa pada mata pelajaran PKn pokok bahasan politik luar negeri, dengan alokasi waktu 2 x 35 menit (kegiatan awal 10 menit, kegiatan inti 50 menit, dan kegiatan akhir 10 menit). Adapun kegiatan pembelajaran sesuai dengan skenario pembelajaran yang telah disusun adalah sebagai berikut: mengucapkan salam pembuka, mengkondisikan ruang belajar (kelas), mengabsen siswa, melakukan appersepsi, memotivasi siswa, menjelaskan konsep-konsep pelajaran yang akan dipelajari, selanjutnya guru membuka pelajaran dengan menyampaikan rancangan materi politik luar negeri melalui penggunaan model pembelajaran kooperatif tipe tari bambu yang bertujuan untuk meningkatkan minat belajar siswa. Dengan menggunakan model pembelajaran kooperatif tipe tari bambu ini, siswa akan berminat, aktif, sehingga akan berdampak pada hasil belajar siswa dan membantu siswa mengetahui apa yang harus dan apa yang tidak harus dilakukan dalam kegiatan pembelajaran. 
Kegiatan yang dilakukan untuk peningkatan minat belajar siswa adalah membagi peserta didik menjadi beberapa kelompok secara heterogen agar merata antara kemampuan masing-masing peserta didik, memberikan informasi kepada siswa bagaimana prosedur model pembelajaran kooperatif tipe tari bambu, menjelaskan materi pelajaran yaitu politik luar negeri dengan kalimatnya sendiri, dengan jelas dan singkat. Selanjutnya guru meminta peserta didik untuk melakukan pemahaman tentanng materi politik luar negeri dengan kalimatnya sendiri, kemudian guru membimbing peserta didik selama proses belajar mengajar.

Setelah peserta didik menyelesaikan tugasnya untuk politik luar negeri dengan waktu yang telah ditentukan oleh guru, kemudian peserta didik didorong untuk saling bertukar informasi tentang hasil tulisannya kepada teman yang berada dihadapannya berdasarkan kelompok yang telah disusun dengan waktu yang telah ditentukan oleh guru. Selanjutnya guru memberikan kesempatan kepada peserta didik untuk bertanya tentang hal-hal yang kurang dimengerti peserta didik pada materi pelajaran politik luar negeri, serta menjelaskan kembali secara singkat, guru bertanya jawab dengan peserta didik tentang seputar materi pelajaran politik luar negeri dan bersama-sama dengan peserta didik membuat kesimpulan.

\section{Pengamatan}

Pada tahap ini, guru bersama guru kelas melakukan observasi guru dan observasi siswa dengan menggunakan alat bantu check list terhadap pelaksanaan kegiatan pembelajaran berlangsung yang menggunakan metode pemberian tugas. Pada saat pembelajaran berlangsung, obsever melakukan observasi terhadap guru, obsever dan guru melakukan observasi perilaku belajar siswa terhadap minat belajar siswa. Setelah pelaksanaan siklus I berakhir, guru memberikan evaluasi belajar untuk menambah penguatan dalam dalam mengetahui minta belajar siswa dan keberhasilan metode pemberian tugas yangn digunakan.

Selama pengamatan, banyak hal yang diperoleh antara lain: 1) siswa belum dapat berinteraksi dengan guru maupun berinteraksi dengan temanteman sekelas, 2) pada kegiatan ini, ada beberapa siswa yang masih enggan untuk mengemukakan pendapatnya, 3) pada kegiatan ini, masih ditemukan siswa yang lebih mementingkan bermain daripada langsung mengerjakan tugas yang diberikan, sehingga mereka tidak dapat menyelesaikan tugas yang diberikan dengan tepat waktu, 4) guru kurang menguasai kelas, 5) ada beberapa siswa yang sama sekali tidak mengerjakan tugas yang diberikan oleh guru, 6) siswa belum aktif dalam menyelesaikan tugas yang telah diberikan.

Hasil observasi pada siklus I menunjukkan bahwa kompetensi guru masih kurang, sehingga perlu dilakukan inovasi lebih lanjut agar pembelajaran mencapai tujuan seperti yang diharapkan. Nilai keseluruhan yang diperoleh sebesar $46 \%$ yang diperoleh rendah sebesar 58\%. Dari hasil perhitungan 
observasi hitungan guru siklus I masih tergolong rendah. Oleh karena itu guru agar dapat meningkatkan kegiatan inti di siklus II agar guru dapat mencapai taraf persentase yang tinggi.

Hasil observasi minat belajar siswa secara individu, yang ditampilkan dalam bentuk tabel di bawah ini:

Tabel 1. Siswa yang Aktif Selama Siklus I

\begin{tabular}{|c|c|c|c|}
\hline Keaktifan & $\mathbf{F}$ & $\mathbf{\%}$ & Keterangan \\
\hline $86 \%-100 \%$ & 0 & 0 & Sangat Berminat \\
\hline $71 \%-85 \%$ & 1 & 3 & Berminat \\
\hline $60 \%-70 \%$ & 5 & 17 & Cukup Berminat \\
\hline$<60 \%$ & 24 & 80 & Kurang Berminat \\
\hline Jumlah & $\mathbf{3 0}$ & $\mathbf{1 0 0}$ & - \\
\hline
\end{tabular}

Berdasarkan Tabel 2 di atas dapat dinyatakan bahwa hasil observasi siklus I yang dilakukan oleh guru dari 30 jumlah siswa, yakni diperoleh nilai sebagai berikut:

a) Siswa yang berminat sebanyak 1 orang dengan persentase $3 \%$

b) Siswa yang cukup berminat sebanyak 5 orang dengan persentase $17 \%$

c) Siswa yang kurang berminat sebanyak 24 orang dengan persentase $80 \%$

Hasil observasi minat belajar siswa secara keseluruhan pada siklus I dapat diketahui bahwa minat belajar siswa Kelas IVB SD Negeri 067690 Medan Johor, dapat dikatakan masih kurang. Hal ini dapat dilihat dari data observasi siswa yang berdasarkan dari indikator minat, yaitu:

1) Observasi siswa mengenai minat mengikuti pelajaran terdiri dari 4 deskriptor, yaitu siswa memperhatikan guru mengajar sebanyak 19 siswa $(63 \%)$, siswa tidak ribut pada saat pembelajaran berlangsung sebanyak 16 siswa (53\%), siswa menulis pelajaran yang disampaikan guru sebanyak 13 siswa (43\%), siswa mampu mempraktekkan pelajaran sesuai dengan permintaan guru sebanyak 9 siswa (30\%)

2) Observasi siswa mengenai minat pemanfaatan waktu belajar terdiri dari 4 deskriptor, yaitu siswa menyusun kegiatan belajar sehari-hari sebanyak 6 siswa (20\%), siswa tidak suka berlama-lama di luar kelas pada saat istirahat sudah berakhir sebanyak 10 siswa (33\%), siswa memanfaatkan waktu istirahat untuk mendiskusikan pelajaran dengan temannya sebanyak 4 siswa (13\%), siswa tidak suka bermain sebelum tugasnya selesai sebanyak 7 siswa $(23 \%)$

3) Observasi siswa mengenai minat mengulang pelajaran kembali terdiri dari 4 deskriptor, yaitu siswa membaca buku pelajaran setelah pelajaran berakhir sebanyak 3 siswa (10\%), siswa membuat ringkasan setelah pelajaran berakhir sebanyak 5 siswa $(17 \%)$, siswa mengingat apa yang 
sudah dipelajari sebanyak 12 siswa (40\%), siswa mengerjakan PR sebanyak 21 siswa $(70 \%)$

4) Observasi siswa mengenai minat menyenangi pelajaran terdiri dari 4 deskriptor, yaitu siswa cepat datang ke sekolah sebanyak 23 siswa (77\%), siswa menyediakan perlengkapan untuk belajar sebanyak 13 siswa $(43 \%)$, siswa memberi tanda pada hal-hal yang penting sebanyak 4 siswa $(13 \%)$, siswa selalu bersemangat pada saat mengikuti pembelajaran sebanyak 8 siswa $(27 \%)$

5) Observasi siswa mengenai minat aktif di dalam kelas terdiri dari 4 deskriptor, yaitu siswa selalu menulis dan mencatat pelajaran penting sebanyak 6 siswa (20\%), siswa sering bertanya sebanyak 4 siswa (13\%), siswa sering menjawab pertanyaan sebanyak 4 siswa $(13 \%)$, siswa selalu mengeluarkan pendapat dalam diskusi kelompok sebanyak 7 siswa $(23 \%)$

Dari hasil observasi siklus I pada tabel di atas masih tergolong kurang. Oleh karena itu guru melanjutkan kegiatan ini ke siklus II agar indikatorindikator observasi siswa dapat mencapai taraf persentase yang tinggi.

\section{Refleksi}

Hasil observasi siklus I yang dilakukan oleh guru dari 30 jumlah siswa, yakni diperoleh nilai sebagai berikut: Siswa yang kurang berminat sebanyak 24 orang dengan persentase $80 \%$. Dari hasil observasi siswa yang telah dilakukan pada siklus I, maka guru melakukan refleksi pada siklus I yang hasilnya adalah: 1) guru kurang menguasai kelas dengan baik, 2) siswa belum aktif dalam menjawab/menyelesaikan tugas yang diberikan guru, karena guru kurang menguasai model pembelajaran, 2) di dalam proses pembelajaran, guru belum dapat menggunakan waktu yang efektif sehingga tujuan pembelajaran belum tercapai, 3) aktivitas guru dalam bertanya kepada siswa, memperhatikan dan membimbing siswa harus lebih ditingkatkan lagi, 4) tahap kegiatan akhir, guru diharapkan dapat melaksanakan penilaian pembelajaran dan lebih sempurna lagi dalam merangkum isi pelajaran, 5) lebih memfokuskan menyelesaikan tugas siswa dalam menyelesaikan soal, serta saling berinteraksi mengeluarkan pendapat tentang materi dengan teman dalam kelompoknya.

\section{Siklus II}

\section{Perencanaan}

Tahap perencanaan pada siklus II merupakan hasil refleksi dari siklus I dimana hasil pada siklus I belum mencapai tujuan yang telah ditetapkan. Pada tahap siklus II ini guru membuat perencanaan tindakan untuk meningkatkan kemampuan siswa dalam menyelesaikan soal. Adapun Standar Kompetensi (SK) yang dibahas dalam kegiatan pembelajaran tersebut adalah memahami tentang politik luar negeri. Dengan kompetensi Dasar (KD) menanggapi tentang politik luar negeri serta menyusun kelompok belajar siswa. 
Langkah-langkah yang disusun dalam RPP dengan menggunakan model pembelajaran kooperatif tipe tari bambu, dimana model pembelajaran ini akan mengaktifkan siswa untuk mempelajari dan mengerjakan latihan baik secara individu maupun berkelompok. Sedangkan instrumen penelitian adalah lembar observasi. Pada siklus ini dilakukan 2 kali pertemuan, pertemuan berlangsung selama 4 jam pelajaran $(4 \times 35$ menit).

\section{Pelaksanaan}

Pada kegiatan ini guru menerapkan penggunaan model pembelajaran kooperatif tipe tari bambu yang bertujuan untuk meningkatkan minat belajar siswa pada mata pelajaran PKn pokok bahasan politik luar negeri, dengan alokasi waktu 2 x 35 menit (kegiatan awal 10 menit, kegiatan inti 50 menit, dan kegiatan akhir 10 menit). Adapun kegiatan pembelajaran sesuai dengan skenario pembelajaran yang telah disusun adalah sebagai berikut: mengucapkan salam pembuka, mengkondisikan ruang belajar (kelas), mengabsen siswa, melakukan appersepsi, memotivasi siswa, menjelaskan konsep-konsep pelajaran yang akan dipelajari, selanjutnya guru membuka pelajaran dengan menyampaikan rancangan materi politik luar negeri melalui penggunaan model pembelajaran kooperatif tipe tari bambu yang bertujuan untuk meningkatkan minat belajar siswa. Dengan menggunakan model pembelajaran kooperatif tipe tari bambu ini, siswa akan berminat, aktif, sehingga akan berdampak pada hasil belajar siswa dan membantu siswa mengetahui apa yang harus dan apa yang tidak harus dilakukan dalam kegiatan pembelajaran.

Setelah peserta didik menyelesaikan tugasnya untuk politik luar negeri berdasarkan dengan waktu yang telah ditentukan oleh guru, kemudian peserta didik didorong untuk saling bertukar informasi tentang hasil tulisannya kepada teman yang berada di hadapannya berdasarkan kelompok yang telah disusun dengan waktu yang telah ditentukan oleh guru. Selanjutnya guru memberikan kesempatan kepada peserta didik untuk bertanya tentang hal-hal yang kurang dimengerti peserta didik pada materi pelajaran politik luar negeri, serta menjelaskan kembali secara singkat, guru bertanya jawab dengan peserta didik tentang seputar materi pelajaran politik luar negeri dan bersama-sama dengan peserta didik membuat kesimpulan.

\section{Pengamatan}

Pada tahap ini, guru kelas melakukan observasi guru dan observasi siswa dengan menggunakan alat bantu check list terhadap pelaksanaan kegiatan pembelajaran berlangsung yang menggunakan metode pemberian tugas. Pada saat pembelajaran berlangsung, obsever melakukan observasi terhadap guru, obsever dan guru melakukan observasi perilaku belajar siswa terhadap minat belajar siswa. Setelah pelaksanaan siklus II berakhir, guru memberikan evaluasi belajar untuk menambah penguatan dalam dalam 
mengetahui minta belajar siswa dan keberhasilan metode pemberian tugas yang digunakan.

Selama observasi banyak hal yang diperoleh antara lain: 1) siswa cepat berinteraksi dengan guru maupun berinteraksi dengan teman-teman sekelas, 2) pada tahap ini siswa tidak enggan lagi untuk mengemukakan pendapatnya, 3) siswa selalu mengikuti kegiatan pembelajaran dengan penuh semangat tinggi dan tidak cepat putus asa dalam mengerjakan tugas yang diberikan oleh guru, 4) guru sudah dapat menguasai kelas dengan baik, 5) pada kegiatan ini siswa sudah langsung mengerjakan tugas yang diberikan, sehingga mereka telah bertanggung jawab dengan tugas yang deiberikan, 6) siswa sudah aktif dalam politik luar negeri melalui gambar yang ditunjukkan kepadanya.

Hasil observasi guru selanjutnya menunjukkan bahwa kompetensi guru telah mengalami perubahan dan mencapai taraf persentase yang lebih tinggi, namun masih terdapat beberapa yang masih memiliki nilai rendah, sehingga perlu dilakukan inovasi lebih lanjut agar pembelajaran mencapai tujuan seperti yang diharapkan. Pada siklus II observasi guru telah mengalami perubahan dan mencapai taraf persentase yang tinggi. Hal ini dapat dilihat dari nilai keseluruhan yang diperoleh sebesar 72, (\%) atau persen yang diperoleh sebesar 90\%. Jumlah siswa yang aktif dan berminat dirangkum pada Tabel berikut ini:

Tabel 2. Siswa yang Aktif Selama Siklus II

\begin{tabular}{|c|c|c|c|}
\hline Keaktifan & $\mathbf{F}$ & $\mathbf{\%}$ & Keterangan \\
\hline $86 \%-100 \%$ & 20 & 67 & Sangat Berminat \\
\hline $71 \%-85 \%$ & 10 & 33 & Berminat \\
\hline $60 \%-70 \%$ & - & - & Cukup Berminat \\
\hline$<60 \%$ & - & - & Kurang Berminat \\
\hline Jumlah & $\mathbf{3 0}$ & $\mathbf{1 0 0}$ & - \\
\hline
\end{tabular}

Berdasarkan data dapat dinyatakan bahwa hasil observasi siklus II yang dilakukan oleh guru dari 30 jumlah siswa, yakni diperoleh nilai sebagai berikut:

a) Siswa yang sangat berminat sebanyak 20 orang dengan persentase $67 \%$

b) Siswa yang berminat sebanyak 10 orang dengan persentase $33 \%$

Dari data hasil observasi siswa pada siklus II dapat diketahui bahwa minat belajar siswa Kelas IVB SD Negeri 067690 Medan Johor. dapat dikatakan sudah lebih meningkat. Hal ini dapat dilihat dari data observasi siswa yang berdasarkan dari indikator minat, yaitu:

1) Observasi siswa mengenai minat mengikuti pelajaran terdiri dari 4 deskriptor, yaitu siswa memperhatikan guru mengajar sebanyak 29 siswa $(97 \%)$, siswa tidak ribut pada saat pembelajaran berlangsung sebanyak 25 siswa (83\%), siswa menulis pelajaran yang disampaikan guru sebanyak 26 siswa (87\%), siswa mampu mempraktekkan pelajaran sesuai dengan permintaan guru sebanyak 24 siswa (80\%). 
2) Observasi siswa mengenai minat pemanfaatan waktu belajar terdiri dari 4 deskriptor, yaitu siswa menyusun kegiatan belajar sehari-hari sebanyak 24 siswa (80\%), siswa tidak suka berlama-lama di luar kelas pada saat istirahat sudah berakhir sebanyak 26 siswa $(87 \%)$, siswa memanfaatkan waktu istirahat untuk mendiskusikan pelajaran dengan temannya sebanyak 23 siswa $(77 \%)$, siswa tidak suka bermain sebelum tugasnya selesai sebanyak 27 siswa $(90 \%)$.

3) Observasi siswa mengenai minat mengulang pelajaran kembali terdiri dari 4 deskriptor, yaitu siswa membaca buku pelajaran setelah pelajaran berakhir sebanyak 24 siswa $(80 \%)$, siswa membuat ringkasan setelah pelajaran berakhir sebanyak 26 siswa $(87 \%)$, siswa mengingat apa yang sudah dipelajari sebanyak 28 siswa (93\%), siswa mengerjakan PR sebanyak 30 siswa $(100 \%)$.

4) Observasi siswa mengenai minat menyenangi pelajaran terdiri dari 4 deskriptor, yaitu siswa cepat datang ke sekolah sebanyak 29 siswa (97\%), siswa menyediakan perlengkapan untuk belajar sebanyak 30siswa $(100 \%)$, siswa memberi tanda pada hal-hal yang penting sebanyak 24 siswa $(80 \%)$, siswa selalu bersemangat pada saat mengikuti pembelajaran sebanyak 22 siswa $(73 \%)$

5) Observasi siswa mengenai minat aktif di dalam kelas terdiri dari 4 deskriptor, yaitu siswa selalu menulis dan mencatat pelajaran penting sebanyak 27 siswa (90\%), siswa sering bertanya sebanyak 24 siswa (80\%), siswa sering menjawab pertanyaan sebanyak 24 siswa $(80 \%)$, siswa selalu mengeluarkan pendapat dalam diskusi kelompok sebanyak 26 siswa $(87 \%)$.

\section{Refleksi}

Hasil observasi siklus II yang dilakukan oleh guru dari 30 jumlah siswa, yakni diperoleh nilai sebagai berikut: Siswa yang berminat sebanyak 20 orang dengan persentase $67 \%$. Dari hasil observasi siswa yang telah dilakukan pada siklus II, maka hasilnya adalah: 1) Guru sudah menguasai kelas dengan baik, karena guru sudah lebih menguasai bahan ajar, 2) siswa sudah aktif dalam menjawab/menyelesaikan tugas yang diberikan guru, karena guru sudah menguasai model pembelajaran dan menggunakan media gambar, 3) di dalam proses pembelajaran, guru sudah dapat menggunakan waktu yang efektif sehingga tujuan pembelajaran tercapai, 4) aktivitas guru dalam bertanya kepada siswa, sudah cukup tinggi, memperhatikan dan membimbing siswa sudah meningkat, karena interaksi antara guru dan siswa pada saat proses belajar mengajar berlangsung dengan cukup baik, 5) tahap kegiatan akhir, guru sudah dapat melaksanakan penilaian pembelajaran dan lebih sempurna lagi dalam merangkum isi pelajaran. Berdasarkan hasil observasi yang telah dilakukan pada pelajaran PKn pokok bahasan politik luar negeri di siklus II sudah sangat baik dalam kegiatan pembelajaran. Peningkatan minat belajar siswa melalui penggunaan model pembelajaran kooperatif tipe tari bambu 
telah tercapai dengan baik, sehingga tidak perlu lagi dilanjutkan ke siklus berikutnya.

\section{KESIMPULAN}

Berdasarkan hasil dan pembahasan penelitian, dapat diperoleh kesimpulan bahwa dengan menggunakan model pembelajaran kooperatif tipe tari bambu, dapat meningkatkan minat belajar siswa pada pokok bahasan politik luar negeri di Kelas IVB SD Negeri 067690 Medan Johor. Maka dalam hal ini guru dapat membuat kesimpulan sebagai berikut:

1) Dengan menggunakan model pembelajaran kooperatif tipe tari bambu, dapat meningkatkan minat belajar siswa dalam mata pelajaran PKn pada pokok bahasan politik luar negeri di Kelas IVB SD Negeri 067690 Medan Johor.

2) Pada observasi minat belajar siswa siklus I rata-rata nilai keseluruhan yang diperoleh hanya mencapai 44, persen (\%) yang diperoleh sebesar 55\%. Dari hasil hitungan observasi siswa siklus I masih tergolong rendah. Pada siklus II rata-rata nilai keseluruhan yang diperoleh yaitu sebesar 69, persen (\%) yang diperoleh adalah sebesar $87 \%$. Pada siklus II dapat dilihat bahwa guru sudah meningkatkan penggunaan model pembelajaran kooperatif tipe tari bambu dengan baik dan perilaku belajar siswa sudah meningkat.

\section{REFERENSI}

Arikunto, S. (2006). Prosedur Penelitian Suatu Pendekatan Praktik. Jakarta: PT. Bumi Aksara.

Djamarah, S. B, dkk. (2006). Strategi Belajar Mengajar. Jakarta: PT. Rineka Cipta.

Djaali. (2006). Psikologi Pendidikan. Jakarta: PT. Bumi Aksara.

Isjoni. (2009). Pembelajaran Kooperatif. Yogyakarta: Pustaka Pelajar.

Lie, A. (2010). Cooperative Learning. Jakarta: Grasindo.

Sanjaya, W. (2008). Strategi Pembelajaran. Bandung: Kencana.

Slameto. (2010). Belajar dan Faktor-faktor yang Mempengaruhinya. Jakarta: PT. Rineka Cipta.

Syah, M. (2010). Psikologi Pendidikan. Bandung: Remaja Rosdakarya. 